\title{
Industrial Balladry, Mass Culture, and the Politics of Realism in Cold War Britain
}

ROSS COLE

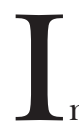

the late 1950s Ewan MacColl, Charles Parker, and Peggy Seeger embarked on a collaboration that epitomized what would become known as the second British folk revival. Commissioned, funded, and eventually axed by the BBC for financial reasons, this project was unprecedented: a series of feature-length radio programs broadcast on the Home Service that set out to document working-class culture through montages of oral testimony interleaved with new songs composed in pastiche ballad form. ${ }^{1}$ The key figure in this project was Salford-born MacColl (an alias adopted by James Henry Miller to emphasize his Scottish heritage and camouflage military desertion during World War II) — autodidact, agit-prop playwright, actor, recording artist, songsmith, and stalwart Marxist. ${ }^{2}$ Two of these programs in particular,

\begin{abstract}
My heartfelt thanks go to Nicholas Cook, Philip V. Bohlman, Marina Frolova-Walker, Vic Gammon, Phil Child, Oskar Cox Jensen, Kate Guthrie, Chris Townsend, and the anonymous reviewers for this journal. Special thanks also go to Peggy Seeger for taking the time to discuss this topic with me. Funding for this project was provided by the UK Arts and Humanities Research Council.
\end{abstract}

${ }^{1}$ Peter Cox, Set into Song: Ewan MacColl, Charles Parker, Peggy Seeger, and the Radio Ballads (Cambridge: Labatie Books, 2008); and Ewan MacColl, "The Radio Ballads: How They Were Made, When and By Whom" (1981), http://www.peggyseeger.com/ discography/ballads. The eight radio ballads are available remastered from Topic Records (TSCD801-808) 8 compact discs, 2008.

2 Ben Harker, Class Act: The Cultural and Political Life of Ewan MacColl (London: Pluto Press, 2007); and Baz Kershaw, ed., The Cambridge History of British Theatre: Volume 3, Since 1895 (Cambridge: Cambridge University Press, 2004).

The Journal of Musicology, Vol. 34, Issue 3, pp. 354-390, ISSN 0277-9269, electronic ISSN 1533-8347. (C 2017 by The Regents of the University of California. All rights reserved. Please direct all requests for permission to photocopy or reproduce article content through the University of California Press's Reprints and Permissions web page, www.ucpress.edu/journals.php?p=reprints. DOI: https://doi.org/10.1525/JM.2017.34.3.354 
The Ballad of John Axon and The Big Hewer, illustrate how MacColl's highly politicized "worship of big industry" was put into practice. ${ }^{3}$ Given that both of these programs were aired as far afield as New York City's WBAI during the 1960s, such work warrants attention for the ways in which a certain coterie of Marxists aligned with the Communist Party of Great Britain (hereafter CPGB) and its subsidiary, the Workers' Music Association, manufactured representations of British working-class life. ${ }^{4}$ Indeed, as David Cannadine reminds us, class itself is a history of ideas about society rather than an empirical description and thus demands critique as a series of devices veiling complex and protean social experience. ${ }^{5}$

These programs were a result of MacColl's longstanding faith in the power of vernacular culture stemming from his days in Theatre Workshop, combined with a transatlantic movement dedicated to "roots" music. ${ }^{6}$ As MacColl noted at the time: "the generation who lived through the war suddenly identified themselves with New Orleans and discovered recordings of the great blues singers." ${ }^{\prime 7}$ The result was a national skiffle craze dedicated to amateur performances of what one New York Times reporter described as "pseudo-Leadbelly country and western tunes, with a crude vamp accompaniment consisting of guitar and washtub bass, kazoo, and other primitive musical instruments." ${ }^{8}$ By the early 1960s, as skiffle mania subsided, crowds of young bohemian "folkniks" began flocking to London's folk clubs (commonly held in pubs) and Soho coffee houses such as the Partisan, often because of related involvement in the New Left or the Campaign for Nuclear Disarmament (hereafter CND).

MacColl was a central figure in this flourishing scene on both sides of the Atlantic. At his New York concert debut with Peggy Seeger in December 1960, the critic Robert Shelton (famous for helping to launch the career of Bob Dylan) dubbed him "Britain's leading folk singer": this "doughty, bearded baritone," Shelton wrote, was a "virtuoso performer" with a keen appreciation of the theatrical:

${ }^{3}$ Peggy Seeger, telephone conversation with author, 5 May 2016.

4 "Radio," New York Times, 17 February 1962, 43; "Radio," New York Times, 26 February 1966, 34. On the CPGB, see James Eaden and David Renton, The Communist Party of Great Britain Since 1920 (Houndmills: Palgrave, 2002).

${ }^{5}$ David Cannadine, Class in Britain (London: Penguin, 2000), 171.

${ }^{6}$ See Ronald D. Cohen and Rachel Clare Donaldson, Roots of the Revival: American and British Folk Music in the 1950s (Urbana: University of Illinois Press, 2014); George McKay, Circular Breathing: The Cultural Politics of Jazz in Britain (Durham, NC: Duke University Press, 2005); Roberta Freund Schwartz, How Britain Got the Blues: The Transmission and Reception of American Blues Style in the United Kingdom (Aldershot: Ashgate, 2007); and Benjamin Filene, Romancing the Folk: Public Memory and American Roots Music (Chapel Hill: University of North Carolina Press, 2000).

7 Quoted in "Living Oral Tradition in Popular Art," The Times, 28 September 1961, 16.

8 David Lewiston, "English 'Folkniks' Shake Up Old Tradition," New York Times, 29 January 1961, 11. 
[He] strode on to the stage of Carnegie Hall Saturday night, sat down casually on a chair turned backwards, sipped a glass of water, cupped his hand near his ear, closed his eyes and proceeded to give one of the most substantial and enjoyable folk concerts New York has had in several seasons.... Mr. MacColl's mastery of mood, scene and vocal control were evident everywhere. ${ }^{9}$

In other words, MacColl was adept at staging a paradigm of unstudied authenticity. Directing attention toward native song traditions and what he postulated as an affinity "between English street ballads and jazz," MacColl saw this revival as being not only musical, but also linguistic. ${ }^{10}$ A special correspondent for The Times noted in 1961, for instance, that MacColl found among those interviewed for the radio ballads "a vividness of speech, an element of fantasy, that he believes to have been lost in literary English." 11 This "unselfconscious richness" not able to be reproduced by actors- "for speech," MacColl stressed, is "a crystallization of a man's whole experience" — was what he aimed to capture and promote. ${ }^{12}$

Positioning these voices on the national airwaves and crafting songs based on their lives was a manifestation of MacColl's effort to smuggle "folk" creation inside the mass media, aiming to broaden its purview while demonstrating that such material could survive in a thoroughly mediatized environment. How this end was to be achieved, however, betrayed a fault line running through the programs. As MacColl himself intimated: "I don't think we can use popular speech just as it stands, but if we could discover how people make idioms and extend their speech as Bartók extended folk dance music into art music.... For me, this is one of the greatest lessons for artistic creation in our time." ${ }^{13}$ Pertinently titled "Popular Art for a Cultural Minority," a contemporaneous review underscored this issue, suggesting that by using American music and "playing in a highbrow way with [their] theme," MacColl's ballads "seemed to carry the story quite a considerable distance from actuality." 14

Indeed, the radio ballads formed part of a radical agenda inseparable from MacColl's past. Driven by what Seeger later described as "hatred of the upper class, of capitalism, of the system," MacColl had laid out this vision of industrial balladry in an idiosyncratic preface to the 1954 anthology The Shuttle and Cage:

9 Robert Shelton, "Ewan MacColl, in Debut Here, Offers Concert of Folk Music," New York Times, 5 December 1960, 44.

10 "Living Oral Tradition."

11 Ibid.

12 Ibid.

13 Ibid.

14 "Popular Art for a Cultural Minority," The Times, 6 November 1959, 4. 
There are no nightingales in these songs, no flowers-and the sun is rarely mentioned; their themes are work, poverty, hunger and exploitation. They should be sung to the accompaniment of pneumatic drills and swinging hammers, they should be bawled above the hum of turbines and the clatter of looms for they are songs of toil, anthems of the industrial age.... If you have spent your life striving desperately to make ends meet; if you have worked yourself to a standstill and still been unable to feed the kids properly, then you will know why these songs were made. If you have worked in a hot pit, wearing nothing but your boots and felt that the air you were breathing was liquid fire, then you will know why these songs were made. If you have crouched day after day in a twelve-inch seam of coal with four inches of water in it, and hacked with a small pick until every muscle in your body shrieked in protest—-then you will know why these songs were made. ${ }^{15}$

In spite of such forceful rhetoric, this "folklore of the industrial worker" was chiefly indebted to MacColl's political imagination and the selective mediations of author, singer, and working-class intellectual A. L. Lloyd. ${ }^{16}$ In fact, MacColl had composed several of the anthologized songs himself. Not formally trained in the discipline of ethnography, Lloyd and MacColl were instead devoted to the creation of what Gerald Porter describes as "a new and militant song repertoire" for folk revivalists themselves. ${ }^{17}$ Seeger recalls that she and MacColl saw such proselytization as a form of "guerrilla warfare" against a culture "where the musical dictatorship seem[ed] to be unassailable": his activism, she notes, "was the constant, central core of his life.... He had a worldview into which everything fitted."18

Although Ben Harker argues that MacColl defined such ideas "against what he saw as earlier folklorists' construction of folk music as a rosy, reassuring window on to a vanished rural past," for Marxists invested in the promotion of laboring culture, songs by and about industrial workers were simultaneously validated as the inheritor of prior

${ }^{15}$ Peggy Seeger, "Introduction," in Ewan MacColl, Journeyman: An Autobiography (London: Sidgwick and Jackson, 1990), 4; Ewan MacColl, ed., The Shuttle and Cage: Industrial Folk-Ballads (London: Workers' Music Association, 1954), unpaginated.

${ }^{16}$ See Dave Arthur, Bert: The Life and Times of A. L. Lloyd (London: Pluto Press, 2012); and Stephen D. Winick, "A. L. Lloyd and Reynardine: Authenticity and Authorship in the Afterlife of a British Broadside Ballad," Folklore 115 (2004): 286-308.

${ }^{17}$ Gerald Porter, "'The World's Ill-Divided': The Communist Party and Progressive Song," in A Weapon in the Struggle: The Cultural History of the Communist Party in Britain, ed. Andy Croft (London: Pluto Press, 1998): 171-91, at 183. More broadly, see Tamara E. Livingston, "Music Revivals: Towards a General Theory," Ethnomusicology 43 (1999): 66-85; Kay Kaufman Shelemay, "Musical Communities: Rethinking the Collective in Music," Journal of the American Musicological Society 64 (2011): 349-90; and Caroline Bithell and Juniper Hill, eds., The Oxford Handbook of Music Revival (New York: Oxford University Press, 2014).

${ }^{18}$ Seeger, "Introduction," 1, 4. 
folkloric epistemology. ${ }^{19}$ There may have been neither flora nor fauna in The Shuttle and Cage, but there were still folk-metamorphosed from their former feudal innocence to become laborers in the furnaces and warrens of capitalist toil. The rural folk, in other words, had become the very urban proletariat they had initially been invented to oppose. Reshaped with reference to new socio-economic conditions, the conceptual architecture provided by the Folk-Song Society and the work of collectors such as Cecil J. Sharp haunted Lloyd's and MacColl's practice. By retaining the idea of folksong, as Dave Harker notes, Lloyd was forced to "reconcile the theory with the fact that the 'folk' had changed." 20 Simultaneously rejecting and respectfully building on fin-de-siècle discourse, their unequivocally masculine vision of folksong transposed ideas of pastoral authenticity onto environments defined by working-class valor, revealing a paradoxical attraction toward (as an embodiment of communal class consciousness and a reflection of Soviet state planning) and loathing of (as an exemplar of capitalist injustice and expansionism) industrialized modernity. The theoretical realignment wrought by Lloyd and MacColl during this period would become the defining feature of postwar revivalism.

A question that tends to be neglected in regard to the postwar folk revival is precisely why British Marxists wished to create such heroic eulogies for working-class identity during the 1950s. In what follows, I provide an answer by looking at affluence, gender, the politics of social realism (distinct from the convoluted project of Soviet socialist realism), and anxieties surrounding mass culture within the New Left. In so doing, I trace the ways in which what Anna Vaninskaya terms "romantic socialism" was adopted by folksong enthusiasts and directed toward industrial working-class culture. Identifying links between William Morris and George Orwell, Vaninskaya argues that this janiform literary construction united "a curious mixture of traditionalism and social critique" predicated on nostalgia for rural life and the national past. ${ }^{21}$ Supporting

19 Harker, Class Act, 106. See Ross Cole, "Ballads, Blues, and Alterity" (Ph.D. diss., University of Cambridge, 2015).

20 Dave Harker, Fakesong: The Manufacture of British "folksong" 1700 to the Present Day (Milton Keynes: Open University Press, 1985), 244. See also Georgina Boyes, The Imagined Village: Culture, Ideology and the English Folk Revival (Manchester: Manchester University Press, 1993); John Francmanis, "National Music to National Redeemer: The Consolidation of a 'Folk-Song' Construct in Edwardian England," Popular Music 21 (2002): 1-25; Robin D. G. Kelley, "Notes on Deconstructing 'The Folk,"' American Historical Review 97 (1992): 1400-1408; Regina Bendix, In Search of Authenticity: The Formation of Folklore Studies (Madison: University of Wisconsin Press, 1997); and Matthew Gelbart, The Invention of "Folk Music" and "Art Music": Emerging Concepts from Ossian to Wagner (Cambridge: Cambridge University Press, 2007).

${ }^{21}$ Anna Vaninskaya, "Janus-Faced Fictions: Socialism as Utopia and Dystopia in William Morris and George Orwell," Utopian Studies 14 (2003): 83-98, at 93. Vaninskaya 
a vision at once authoritarian and democratic, MacColl shared in this fury over exploitation and inequality but grafted heavy urban industry (railways, road building, fishing, and mining) onto spaces formerly reserved for agrarian paradigms. Such a transition shadows and yet destabilizes what Raymond Williams described as the pull of rural symbolism "towards old ways, human ways, natural ways," in contrast to understandings of the city that conventionally lean "towards progress, modernization, development." 22 Through the early radio ballads, this juxtaposition was complicated as folkloric nostalgia was rearticulated and projected onto new working-class contexts, generating the very same misreadings of vernacular culture perpetrated by the Edwardian folk revival.

\section{A. L. Lloyd and the American Example}

Given the powerful imaginative legacies of the fin-de-siècle revolving around urbanization and so-called peasant culture, the most striking shift in mid-twentieth-century folksong discourse is from a notion of ballads as pre-modern rural "survivals" to paradigms of industrial urbanity, revolutionary class struggle, and tools for contemporaneous political dissent. ${ }^{23}$ Indeed, it is hard to imagine a more thorough inversion of Cecil Sharp's pastoral ideals under the same banner. ${ }^{24}$ Eric Winter, editor of Sing magazine, declared in 1958 that owing to the postwar revival "folk-song" was "no longer the exclusive province of cycling parsons and genteel schoolmistresses." ${ }^{25}$ The writer largely responsible for this discursive shift, I want to suggest, is Lloyd-a journalist, literary translator, singer, and sometime whaler who earned himself the nickname "the Dean" among revivalists. ${ }^{26}$ Although his early work The Singing Englishman had embraced a Marxist reading of British history aligned with the Communist Party Historians' Group, it was only with the appearance of

cites A. L. Morton and E. P. Thompson in this romantic socialist tradition-both key influences on Lloyd.

${ }^{22}$ Raymond Williams, The Country and the City (Nottingham: Spokesman, 2011 [orig. pub. 1973]), 297.

${ }_{23}$ On the history of the ballad, see Nick Groom, The Making of Percy's Reliques (Oxford: Oxford University Press, 1999); Adam Fox, Oral and Literate Culture in England, 1500-1700 (Oxford: Oxford University Press, 2000); David Atkinson, The English Traditional Ballad: Theory, Method, and Practice (Aldershot: Ashgate, 2002); Maureen N. McLane, Balladeering, Minstrelsy, and the Making of British Romantic Poetry (Cambridge: Cambridge University Press, 2008); Mary Ellen Brown, Child's Unfinished Masterpiece: The English and Scottish Popular Ballads (Urbana: University of Illinois Press, 2011); and Arthur Knevett and Vic Gammon, "English Folk Song Collectors and the Idea of the Peasant," Folk Music Journal 11 (2016): 42-67.

${ }_{24}$ Sharp's ideas were laid out most famously in English Folk-Song: Some Conclusions (London: Simpkin \& Co., Novello \& Co., 1907).

${ }^{25}$ Eric Winter, "The Flowers of Manchester," Manchester Guardian, 3 March 1958, 5.

${ }^{26}$ Ibid. 
functionalist scholarship from the United States that Lloyd turned his attention to industrial folklore, the subject for which he would become best known.

Lloyd concluded in 1944 that folksong was "the product of a social system that has come to an end": the most deadly factor in the regression of such practice, he argued, was "the development of industrial technique." 27 "At this moment," he asserted, "we have no great body of fine folksong that is bound close to our social life and the times we live in and the way we go about our work." 28 In the introduction to an anthology indebted to Carl Sandburg published the following year, however, Lloyd amended this position. Urban environments, he noted, were in fact capable of producing material that reflected modern experience of working-class life, albeit from a virile and normatively heterosexual perspective: "American folk poetry is still thriving. . . Every day new songs are made up and quickly assimilated into the national tradition-songs not only of boy meets girl, but also of boy builds railroads and dams, and goes on strike or on relief or moves out of dusty country, or flies 'planes and fights Fascists." ${ }^{29}$ Such adventures, of course, reflected the experiences of Dust Bowl troubadour Woody Guthrie outlined in Bound for Glory. ${ }^{30}$

By 1946 Lloyd had consolidated this transformation in his thinking through engagement with the work of Benjamin Botkin, a prominent American folklorist previously involved in the Federal Writers' Projectone of many ameliorative New Deal initiatives employing artists, intellectuals, musicians, and authors in public works during the Great Depression. ${ }^{31}$ During this period the Roosevelt administration had assimilated a Leftist celebration of the masses as a form of democratic, patriotic heritage. Botkin's work thus echoed a process of what Jerre Mangione has termed "native self-discovery" through singular attention to working-class culture and the dispossessed. ${ }^{32}$ Underpinning this ethos was a paradigm shift away from antiquarianism and evolutionary philosophy toward practical, egalitarian ideals aligned with the Popular Front. ${ }^{33}$ Laying the

27 A. L. Lloyd, The Singing Englishman: An Introduction to Folksong (London: Workers' Music Association, 1944), 52.

28 Ibid., 68.

29 A. L. Lloyd, ed., Corn on the Cob: Popular and Traditional Poetry of the U.S.A. (London: Fore Publications, 1945), 16.

${ }^{30}$ Woody Guthrie, Bound for Glory (London: Penguin, 2004 [orig. pub. 1943]).

31 Lawrence Rodgers and Jerrold Hirsch, eds., America's Folklorist: B. A. Botkin and American Culture (Norman: University of Oklahoma Press, 2010); and Jonathan Harris, Federal Art and National Culture: The Politics of Identity in New Deal America (Cambridge: Cambridge University Press, 1995).

32 Jerre Mangione, The Dream and the Deal: The Federal Writers' Project, 1935-1943 (Syracuse: Syracuse University Press, 1996), 50.

33 See Mike Hawkins, Social Darwinism in European and American Thought, 1860-1945: Nature as Model and Nature as Threat (Cambridge: Cambridge University Press, 1997); and 
foundations for urban folk revivalism, Lloyd was instrumental in adapting such ideas to a British context. This functionalist turn, as Benjamin Filene notes, "allowed folklore a political potential" that could move the discipline "beyond its associations with the past and actively and powerfully address the needs of the present." ${ }^{34}$ Such principles were manifest in Botkin's magnum opus, A Treasury of American Folklore, which became available in Britain in an abridged edition titled The American People: In Their Stories, Legends, Tall Tales, Traditions, Ballads and Songs. One sentence in particular must have struck Lloyd with force: "The industrial folk tales and songs in this book," Botkin wrote, "are evidence enough that machinery does not destroy folklore." ${ }^{35}$

Having read the book, Lloyd appeared to undergo a conversion experience, publishing a rave review in the radical British journal Our Time that began polemically by attacking "those who have made of folklore a quaint parsonage affair." ${ }^{36}$ Dismissing Sharp's viewpoint as "nonsensical," Lloyd railed against "antiquarian boys, who don't know great A from a bull's foot about the folk culture of their own day and age" but "have evolved a myopic and snobbish theory that all the ancient orders of folklore (the Child ballads, for instance) are a kind of aristocracy, and all the newer orders are something less than dust." ${ }^{37}$ Anticipating criticism from a fictional skeptic dubbed Comrade Cleverdick who believed that folklore was inconceivable in modern society, Lloyd cited American scholars who "came quickly to discover [that] ... the proper study of folklore is the study of working people, now as much as any time; for industrialism doesn't destroy either a folk or their lore." 38 Alongside legendary heroes, he wrote, readers could find in the anthology "the big mythical men of our own times, the products (are you listening, Comrade Cleverdick?) of an industrial folklore in a society that's as capitalist as can be." ${ }^{39}$ Without admitting to having once ardently endorsed Cleverdick's position, Lloyd ended his review with a vignette that directly contradicted what he had written just two years earlier. In 1944, he had argued that hawkers who "once filled the city streets with music" had finally been "killed by the department stores, by Woolworths"; in 1946, he suggested that "if some

Michael Denning, The Cultural Front: The Laboring of American Culture in the Twentieth Century (London: Verso, 1996).

34 Filene, Romancing the Folk, 143.

35 B. A. Botkin, ed., The American People: In Their Stories, Legends, Tall Tales, Traditions, Ballads and Songs (London: Pilot Press, 1946), 12.

36 A. L. Lloyd, "This 'Folk' Business," Our Time 6, no. 2 (1946): 44-46, at 44.

37 Ibid., 45. Such views echoed Child's own concerning broadsides: see Roy Palmer, "'Veritable Dunghills': Professor Child and the Broadside," Folk Music Journal 7 (1996): 155-66; and David Atkinson, "The English Revival Canon: Child Ballads and the Invention of Tradition," Journal of American Folklore 114 (2001): 370-80.

38 Lloyd, "This 'Folk' Business," 45.

39 Ibid. 
people would put their anthropological books away for a moment, and take a walk round Woolworths, say, they might learn a bit more about folkways than they'd bargained for." ${ }^{40}$ Lloyd would later confess that the postwar British folk scene had "followed the American folk song revival that began in the 1930s": MacColl's efforts, he concluded, had borne fruit "only as the American example became clear." ${ }^{41}$

\section{New Aspirations and Cravings}

The 1950s represented a period of flux, unease, and dejection for British radicals-compounded in 1956 by Nikita Khrushchev's denunciation of Stalin and his abuses of power, followed by the Soviet subjugation of a democratic uprising in Hungary. ${ }^{42}$ What was interpreted as a creeping Americanization of British culture, moreover, indicated fissures in the very foundations of a socialist worldview: the working class appeared to be cheerfully embracing what Richard Hoggart memorably characterized as the "cheap gum-chewing pert glibness" of mid-century consumer products rather than proudly ushering in a new world order. ${ }^{43}$ In response, as Dennis Dworkin notes, British Marxist intellectuals began to abandon economism and strove to redefine the relationship between structure and agency through culture. ${ }^{44}$ Positing manual labor as the primary locus of identity and the wellspring of authentic expressivity, MacColl's rendering of working-class life in the radio ballads is inextricably bound up with these debates surrounding the rise of a purportedly classless culture blossoming in the wake of Anglo-American economic stability.

As the decade progressed, Britain was widely considered to have become a society of newly affluent consumers who, in the words of Conservative Prime Minister Harold Macmillan, had "never had it so good"; historian Kenneth O. Morgan, for example, brands the period 1957-61

${ }^{40}$ Lloyd, The Singing Englishman, 68; and idem, "This 'Folk' Business," 46.

41 A. L. Lloyd, Folk Song in England (London: Lawrence \& Wishart, 1967), 394, 395. See also Robbie Lieberman, "My Song is My Weapon": People's Songs, American Communism, and the Politics of Culture, 1930-50 (Urbana: University of Illinois Press, 1989); and Ron Eyerman and Scott Barretta, "From the 30s to the 60s: The Folk Music Revival in the United States," Theory and Society 25 (1996): 501-43.

${ }^{42}$ Lawrence Black, The Political Culture of the Left in Affluent Britain, 1951-64: Old Labour, New Britain? (Basingstoke: Palgrave Macmillan, 2003); and Melvyn P. Leffler and Odd Arne Westad, eds., The Cambridge History of the Cold War: Volume 1, Origins (Cambridge: Cambridge University Press, 2010).

43 Richard Hoggart, The Uses of Literacy: Aspects of Working-Class Life (London: Penguin, 2009 [orig. pub. 1957]), 209. See also John Kenneth Galbraith, The Affluent Society (London: Hamish Hamilton, 1958).

${ }^{44}$ Dennis Dworkin, Cultural Marxism in Postwar Britain: History, the New Left, and the Origins of Cultural Studies (Durham, NC: Duke University Press, 1997). 
"the zenith of one-nation Toryism." 45 Growth in ownership of cars, houses, televisions, and domestic goods matched rising wages, a period of full employment, and the emergence of a teenage subculture with significant disposable income. British society, in other words, appeared to have thrown off the shackles of poverty and austerity to enter a period of unprecedented economic optimism that could provide high standards of living for all and create the basis of a true meritocracy. Comprehensive welfare reform, the Festival of Britain, and the coronation of Queen Elizabeth II seemed to represent what Stuart Laing describes as "not merely the post-war rewards of peace and prosperity, but potentially the epochal moment of British revival" (notwithstanding the embarrassment of Suez). ${ }^{46}$ As Morgan argues: "the moral passion of the thirties [and] the social idealism of the war years was evaporating in favour of a passive, uncomplaining reformism," leaving "an aura of comfort and contentment, of rising expectations and diminishing concern." ${ }^{47}$ It was no coincidence that during this period the Conservative Party won three successive general elections, governing from 1951 to 1964: consciously aligned with the postwar boom, a Tory rhetoric of affluence, aspiration, and classless unity functioned to enforce the credibility of a right-wing government against notions of class enmity. Disconcertingly for the Left, such propaganda seemed to echo profound changes in the electorate itself: during the 1950s, the Conservatives consistently won large swathes of the working-class vote. ${ }^{48}$

More than merely votes, an increasingly moralistic socialism was losing confidence in the historical inevitability of its vision. In Hoggart's words, a "bloodless revolution" appeared to have taken place, erasing the integrity of working-class culture and producing a hollow, barbaric society united solely by mass consumerism. ${ }^{49}$ As sociologist of labor Ferdynand Zweig proposed after extensive fieldwork in the 1950s, British workingclass life found itself "on the move towards new middle-class values" with "new ways of thinking and feeling, a new ethos, new aspirations and cravings": manual workers were ambivalent about trade unionism and, in their quest for comfort and respectability, willing "player[s] of the game."

45 Kenneth O. Morgan, Britain Since 1945: The People's Peace, 3rd edition (Oxford: Oxford University Press, 2001), 158. See also Brian Harrison, Seeking a Role: The United Kingdom, 1951-1970 (Oxford: Oxford University Press, 2009).

46 Stuart Laing, Representations of Working-Class Life, 1957-1964 (Basingstoke: Macmillan, 1986), 9 .

47 Morgan, Britain Since 1945, 137, 157.

48 Dominic Sandbrook, Never Had It So Good: A History of Britain from Suez to the Beatles (London: Abacus, 2006), 51.

49 Hoggart, The Uses of Literacy, 3.

50 Ferdynand Zweig, The Worker in an Affluent Society: Family Life and Industry (London: Heinemann, 1961), ix, 210. 
The "acquisitive society," he wrote, "has succeeded in expanding its frontiers and converting its natural antagonists to its own creed." ${ }^{51}$ In these circumstances, the imagery of the Labour Party seemed hopelessly obsolete-a relic of a once-stratified society, associated with nationalization, rationing, and an unfashionably condescending political agenda. Labour was thus not simply a victim of affluence, but failed to respond to change; as Lawrence Black argues, the party was "neither as able nor willing as Conservatism to build a broad constituency of support from affluence." 52 A Leftist elite, in short, had turned its distaste for mass consumerism into contempt for newly affluent members of society: the fault appeared to lie not in its own political compass, but rather in the working class itself.

\section{Ewan MacColl and the Radio Ballads}

Catalyzed during the mass unemployment of the 1930s, MacColl's political stance remained indelibly marked by a model of class antagonism derived from the $\mathrm{CPGB}$ - by the end of the Second World War, no longer a revolutionary platform but a party veering between reformism and sectarianism, Left patriotism and anti-imperialism, socialism and Stalinism. ${ }^{53}$ MacColl tended to read the early days of the Cold War through a polarizing lens, as Ben Harker notes: "On one side was the decadent bourgeoisie of America, with its corrosive imperialistic culture; on the other, the progressive cultures of the international proletariat, with the Soviet Union in the vanguard." ${ }^{54}$ Lloyd thus bequeathed a contradictory underpinning to the revival: his conceptualization of industrial balladry owed a debt to scholarship from the United States at the very moment that American popular culture was reviled by British communists. In 1952, for instance, the Soviet-subsidized CPGB had issued a call to increase "activity against the Americanisation of Britain's cultural life." 55 Yet like Lloyd American culture fascinated MacColl—demonstrated by his close friendship with Alan Lomax, then in Europe pursuing field recordings and evading McCarthyism. ${ }^{56}$ Characterizing him as "a oneman public relations department for folk music," MacColl remembers

51 Ibid., 212.

52 Black, The Political Culture of the Left, 189.

53 Eaden and Renton, The Communist Party of Great Britain.

54 Harker, Class Act, 122-23.

55 Quoted in Andy Croft, "Authors Take Sides: Writers and the Communist Party, 1920_ 56," in Opening the Books: Essays on the Social and Cultural History of British Communism, ed. Geoff Andrews, Nina Fishman, and Kevin Morgan (London: Pluto Press, 1995): 83-101, at 92.

56 John Szwed, Alan Lomax: The Man Who Recorded the World (London: William Heinemann, 2010); E. David Gregory, "Lomax in London: Alan Lomax, the BBC and the FolkSong Revival in England, 1950-1958," Folk Music Journal 8 (2002): 136-69; and Tom Western, " "The Age of the Golden Ear': The Columbia World Library and Sounding out Post-war Field Recording," Twentieth-Century Music 11 (2014): 275-300. 
being enraptured by Lomax's "chants and hollers learned in the prison camps of Texas and Florida...blues from Mississippi and Tennessee... [and] lowdown ballads from Louisiana"; he confessed to spending more and more time "listening to Alan's enormous collection of tapes... arguing, discussing, learning and trying to acquire [his] worldview." ${ }^{57}$ Grounded in Lomax's ideas, the British revival was thereby driven in part by a translation-via CPGB doctrine-of racialized marginality endemic to the United States into a British politics of class-based authenticity.

Somewhat ironically, therefore, the influence of American folklore theory and vernacular song served to uphold Lloyd's and MacColl's Marxist principles amid a Cold War atmosphere of vociferously antiAmerican sentiment on the Left. Although by the mid-1960s MacColl and Seeger would adopt a rigorous aesthetic purism, in the late 1950s their sonic palette was unashamedly eclectic: the music of the early radio ballads, MacColl admitted, "was rhythmically and harmonically orientated towards the American tradition." $" 58$ Central to such musical catholicism was Peggy Seeger herself, half-sister of Pete, born to musicologist Charles Seeger and the composer Ruth Crawford. Educated at Radcliffe College in Massachusetts, she had travelled across Europe during the mid-1950s before being sought out for her virtuosity on guitar, banjo, Appalachian dulcimer, autoharp, and concertina by Lomax, who asked her to join the transatlantic skiffle group the Ramblers. ${ }^{59}$ Comparing her approach to "a house of varying and sometimes contradictory architectural styles ... with complete fidelity to none," she noted in Sing magazine that the American revival from which she had emerged "included practically every kind of song and instrument." 60

Seeger's contribution to the radio ballads was considerable, as MacColl indicates: "in addition to writing musical arrangements, conducting the recording of the music and playing and singing...she took part in the recording of actuality [spoken material] in the field, transcribed all the recordings, joined with me in choosing and timing actuality sequences, collaborated in creating the script and helped decide which passages of actuality needed a musical commentary" (fig. 1). ${ }^{61}$ In spite of

57 Ewan MacColl, "Folk Narrative," Guardian, 8 September 1960, 6; MacColl, Journeyman, 311, 270-71. See, for example, John A. Lomax and Alan Lomax, eds., American Ballads and Folk Songs (New York: The Macmillan Company, 1934); idem, eds., Negro Folk Songs as Sung by Lead Belly (NewYork: The Macmillan Company, 1936); and idem, eds., Our Singing Country: A Second Volume of American Ballads and Folk Songs (New York: The Macmillan Company, 1941).

58 MacColl, Journeyman, 313.

59 Jean R. Freedman, "Seeger, Peggy," Grove Music Online, accessed 1 May 2016, http://www.oxfordmusiconline.com/subscriber/article/grove/music/51128.

60 Peggy Seeger, "Self-Portrait," Sing 4, no. 6 (1958): 67-68, at 67.

61 MacColl, Journeyman, 315. 
Figure 1. Peggy Seeger and Ewan MacColl performing at the Ballads and Blues Club, London, late 1950s. Charles Parker is just visible to the far left. Photograph: Eddis Thomas. (C) Heritage Image Partnership Ltd., Alamy. Used with permission.

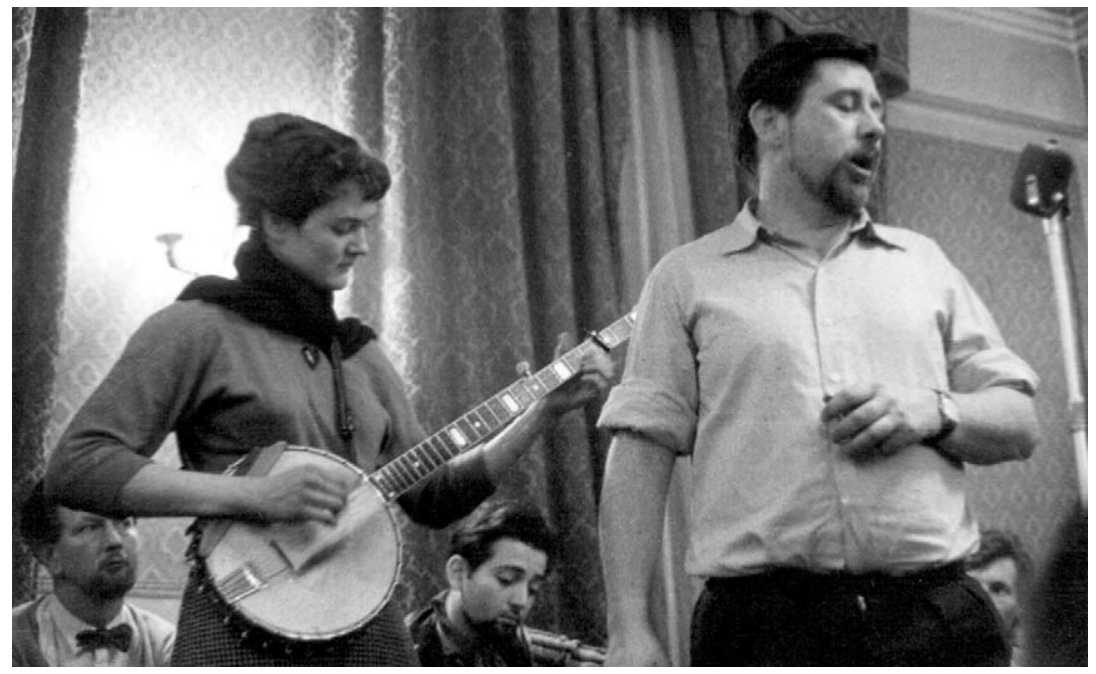

this extensive involvement, the essentialized treatment of gender in the songs and documentary montages is a testament to MacColl's age and prevailing authorial presence. Seeger concedes to following his political instincts and not questioning the situation enough at the time: before the 1970s, she recalls, "I didn't know what a feminist was." ${ }^{62}$ Furthermore, she adds, the themes initially chosen by MacColl for the programs-focused on valiant depictions of heavy industry—necessarily foreclosed the subject positions available to women.

Early impetus for the radio ballads had come from Charles Parker, then a senior features producer at the BBC. A Cambridge graduate who had served aboard submarines during the Second World War, Parker was an unconventional and ambitious perfectionist who, as Paul Long notes, began to show "all the traits of the romantic convert" to the radical Left during his creative involvement with MacColl. ${ }^{63}$

The idea that Parker put forward was for a new type of radio documentary based on the tragic death of railwayman John Axon. Born in Stockport in 1900, by 1948 Axon had worked his way up to the position of

62 Peggy Seeger, telephone conversation with author, 5 May 2016.

63 Paul Long, "British Radio and the Politics of Culture in Post-War Britain: The Work of Charles Parker," The Radio Journal 2 (2004): 131-52, at 140. 
steam-locomotive driver for British Rail. ${ }^{64}$ Nine years later, on the morning of Saturday, 9 February 1957, he was in charge of a freight train from Buxton to Warrington Arpley hauling thirty-three loaded trucks weighing 775 tons with the aid of a bank engine. Shortly before a controlled descent down a one in fifty-eight gradient toward Chapel-en-le-Frith, a fracture occurred in the brake pipe, filling the front cab with high-pressure steam and destroying the braking system. Axon was severely burned, but, with the aid of his fireman Ron Scanlon, was able to apply the brakes on the coal-car; this was still not enough to halt the train before the approaching incline. Ordering Scanlon to jump free and attempt to apply brakes on the individual wagons before they gathered speed, Axon remained on the footplate to warn upcoming signalmen. The points ahead were changed, avoiding derailment and allowing the train to move onto the mainline where it might have been brought under control. Travelling at fifty-five miles per hour, however, Axon's train collided with a freight service heading for Edgeley, killing Axon and the guard of the Edgeley train, John Creamer. Along with the station's signal box, sixty-eight wagons were destroyed, leaving a substantial pile of wreckage. The official accident report recorded that Axon could have saved his life, but instead stayed on the train "to give warning," setting "an outstanding example of devotion to duty." 65 For his courage Axon was posthumously awarded the George Cross-the highest British accolade for civilian heroism. $^{66}$

With its striking similarities to the American railroad song "The Ballad of Casey Jones," this story caught Parker's attention. Just six months after the accident he had secured consent to make the program-his inspiration drawn from Millard Lampell and Earl Robinson's 1942 cantata The Lonesome Train as well as the British Free Cinema movement's commitment to documenting neglected aspects of contemporary vernacular life. ${ }^{67}$ When the BBC commissioned the program-granting use of a state-of-the-art portable tape machine that allowed sound to be recorded on location-Parker wrote enthusiastically to MacColl, requesting his services on a freelance basis as researcher, composer, and performer. ${ }^{68}$ MacColl readily accepted, later noting that the programs presented

64 Philip Carter, “Axon, John,” Oxford Dictionary of National Biography, accessed 30 July 2014, http://www.oxforddnb.com/view/article/101106.

${ }^{65}$ Quoted in ibid.

${ }^{66}$ Harker, Class Act, 131.

67 Long, "British Radio and the Politics of Culture," 136. See also Robert Cantwell, When We Were Good: The Folk Revival (Cambridge, MA: Harvard University Press, 1996); on Free Cinema, see Scott MacKenzie, ed., Film Manifestos and Global Cinema Cultures: A Critical Anthology (Berkeley: University of California Press, 2014), 149-52; and Sarah Street, British National Cinema (London: Routledge, 1997).

68 Harker, Class Act, 130. 
a pioneering form that might answer "the question of whether traditional folk-song was capable of reflecting twentieth-century, industrial society." 69 Preliminary groundwork for each radio ballad would involve wide-ranging field interviews, later edited into intricate sonic collages by Parker, that MacColl used as the basis for original lyrics set to melodies in a folk revivalist style; he described conceiving of these songs as an extension of, or a commentary on, a specific field recording, or as the frame for a particular tableau. ${ }^{70}$

Broadcast on 2 July 1958 - the same year as the first anti-nuclear protest march from London to Aldermaston as well as the Kingston Trio's release of "Tom Dooley"- The Ballad of John Axon featured a diverse array of music revolving around the burgeoning transatlantic nexus of folksong, Trad jazz, and skiffle. Parker saw this amalgam of musical styles as a reflection of the raw field recording in the broadcast, admitting in the Radio Times to taking liberties by "dispensing with acted dialogue or formal narration" and "blending jazz and the organum, austere English ballad with banjo, guitar, [and] harmonica." "71 This "story of an ordinary Englishman of our own times," Parker declared, contained "heroism and humanity enough to fire a hundred songs." 72 Given such power, MacColl recalled, Axon's story had to be told "by the railwaymen themselves and not by actors imitating railwaymen"- as had been protocol on previous BBC documentary features. ${ }^{73}$ A preview in the Manchester Guardian drew attention to this "new and unusual type of broadcast—-the first full 'ballad opera' about a man of our times" that was, in this writer's opinion, "extraordinarily moving and dramatic." ${ }^{\prime 74}$ A review the following day stated:

As the story of John Axon's last run with the 11:15 from Buxton gathered speed and rattled on to its tremendous catastrophe the pulse caught up with the pounding rhythm and the mind caught on to what Ewan MacColl and Charles Parker had been driving at—something like the experience a drowning man is supposed to undergo in his last minutes.... The other aim of the writers of this programme was to honour a hero of the people and the tradition of service out of which his heroism grew, and to do this in something like the idiom of the people, through a series of ballads and a curiously effective sort of recitative with folky overtones linked by scraps of reminiscence and engine-shed lore. ${ }^{75}$

69 MacColl, Journeyman, 327.

${ }^{70}$ Ibid., 313.

${ }^{71}$ Charles Parker, "The Ballad of John Axon," Radio Times, 27 June 1958, 33.

72 Ibid.

73 MacColl, Journeyman, 313.

74 "“The Ballad of John Axon': Broadcast Recalls Heroism," Manchester Guardian, 2 July 1958, 8. $1958,3$.

${ }^{75}$ W. L. W., "A Modern Ballad Opera and a Folk Hero," Manchester Guardian, 3 July 
Winter described the broadcast as a "folksong epic" skillfully exploiting its medium while incorporating "the stuff of which heroic ballads are made." "In the Observer Paul Ferris noted that the program was "a brilliant success" in which "a technique and a subject got married"; offering material that felt "close to life," he remarked, "this was noise with a purpose... sharp and strange and powerful." 77 Two other programs soon followed: Song of a Road, detailing the construction of the London to Yorkshire highway (5 November 1959); and Singing the Fishing, paying tribute to the herring fishing communities of East Anglia and Scotland's Moray Firth (16 August 1960). Ferris concluded that these programs were tapping the sources of "real legend" through songs "charged with sadness or adventure" and were consequently "the most exciting pieces of pure radio you can find nowadays." 78

Titled The Big Hewer, the fourth radio ballad (18 August 1961) explored life in the coalfields of South Wales, the Midlands, Durham, and Northumberland. The eponymous hero was a mythical figure and, as Lloyd later outlined, a means for workers to personify and make sense of the mine itself:

If this superhuman worker has a hundred names and faces his feats are described in much the same terms in South Wales, the Midlands, the North-east. At birth he was six feet tall and weighed eighteen stone. He was a huge eater and a prodigious toiler who would impatiently throw aside his blunted tools and drill with his nose and cut coal with his teeth while holding up the roof with one hand. When the ground settles in the mine, South Wales colliers say: "Big Isaac's working again." In Durham when the timbers groan, they say: "Bob Towers is talking to us."79

Drawing on mythical and dramatic imagery congruent with the history of the ballad form, The Big Hewer translated this collier legend into song. In preparation, MacColl describes dragging himself and the production team through narrow seams-conversing in pithead canteens "with men who hacked words out of their ruined chests" and "in pubs where men drank their beer out of personalised mugs with quotations of Marx and William Morris engraved on the rims." 80

In her review for the Guardian, Mary Crozier asserted that the program's "technique of swinging, rhythmical choruses, interspersed with recordings of the words of miners ... made [it] an impressive experience":

76 Eric Winter, "Ballads and Bravery," Manchester Guardian, 16 October 1958, 7.

77 Paul Ferris, "Noise with a Purpose," Observer, 6 July 1958, 14.

78 Paul Ferris, "Legend in Concrete," Observer, 8 November 1959, 15.

79 Lloyd, Folk Song in England, 335-36.

80 MacColl, Journeyman, 328. 
The miner, as heard here, has an intense and poetic awareness of the elements among which he lives and works; through the eyes of a boy we saw the first descent into the pit, the "new world, a strange world entirely" at the bottom; the utter darkness which presses upon him"you can feel the darkness." In a sequence marked by its bare and tragic feeling, words falling like slow drops of water, the death of a miner in a pit fall was recorded: the body brought home "in its pit dirt" (like the vivid account in Lawrence's Sons and Lovers). And there was that other killer, dust, "the giant killer," taking his time, "he walks into your lungs." Finally there came again the chorus "Out of the dirt and darkness I was born" with its refrain of "Go down." 81

Through these songs and documentary montages, Parker felt proud to be introducing what he claimed was "an entirely new concept of the coalminer." 82

The producers, however, had played a first cut of the program to a group of miners and, as Peter Cox notes, were "taken aback to be told it lacked humour"; without time to emend the entire ballad, their response was to hastily incorporate a section featuring jokes, yarns, and a forcibly jovial song. ${ }^{83}$ Indeed from the documentary recordings it is clear that far from being an earnest and austere ideal, the Big Hewer was often a vehicle for facetious wit: "He had a good remedy for a bad roof, Isaac Lewis. He told the manager that he had a remedy-leave the coal under it," chuckled one man. Another miner agreed that he was unable to "think of anything underground without the humor." The eponymous hero also functioned, as Dave Harker points out, as "a deliberate and grotesque caricature of the self-exploitative worker"-a symbol of prowess, a selfmocking exaggeration, a satirical tool to mock those who undercut pay rates, and "a defensive screen to ward off criticism of what has always been a degrading and dangerous job." ${ }^{84}$ Such misconceptions were symptomatic of Parker, MacColl, and Seeger's status as outsiders. In their analysis of an archetypal Yorkshire mining community published in 1956, the young left-wing sociologists Norman Dennis, Fernando Henriques, and Clifford Slaughter reported that "miners constantly say that no non-miner can appreciate the nature of pitwork." 85 Without senses suitably attuned to the intricacies of mining life, Robert Colls notes, “significant aspects of the miner's village were as ghosts to be walked

81 Mary Crozier, "Radio Ballads," Guardian, 19 August 1961, 3.

82 Quoted in "Change in Style of Documentaries," The Times, 2 August 1961, 5. See also Charles Parker, "The Big Hewer," Radio Times, 10 August 1961, 51.

83 Cox, Set into Song, 114.

84 Dave Harker, One for the Money: Politics and Popular Song (London: Hutchinson, $1980), 183$.

85 Norman Dennis, Fernando Henriques, and Clifford Slaughter, Coal is Our Life: An Analysis of a Yorkshire Mining Community (London: Eyre \& Spottiswoode, 1956), 73. 
through." ${ }^{86}$ The Yorkshire study argued, furthermore, that miners tended not to think "in the abstract terms of social and economic relations ... but in a more concrete way" about the pragmatic issues surrounding daily wage labour and local trade union bureaucracy ${ }^{87}$ In contrast to MacColl's view, the authors noted, miners talked "far, far more about class distinction than they do about class struggle." 88

Although The Big Hewer was characterized in The Times as being "a declaration of the human dignity that is continually eroded by what we normally call "progress," the reviewer also confessed that the program was "not... an exploration of a fascinating piece of industrial folk-lore" but rather "a recreation of the miner's mystique." 89 In the Observer, Ferris described a similar development in the series: whereas previous radio ballads were careful to avoid enshrining workers, The Big Hewer showed "uneasy signs of over-awareness." 90 Outlining a transition away from what he termed "unselfconscious heroism... overheard, not stated," Ferris objected to what he felt was an increasingly theatrical quality to MacColl's portrayal of working-class life. ${ }^{91}$ This disjunction was apparent in the way miners saw the mythical figure and the way the program engaged it as a political allegory-reading workers through the lens of the myth, rather than taking the miners' experiences on their own terms. A later review in The Times suggested that the program recalled the partisan politics of the 1930s. ${ }^{92}$ Commenting on the growing dominance of television, this article proposed that radio was, by contrast, "a medium in which heroes flourish [as] it gives unfettered scope to audience imagination and moves naturally in worlds of legend and magic." 93 This very aspect, however, was seen to be its Achilles's heel: "it is in their extensive reliance on music that the Parker-MacColl programs come closest to distorting their material... doubts begin to creep in when it has the effect not of heightening the atmosphere but simply of inflating it." ${ }^{\prime 94}$

\section{Fight Against the Mass Pop-Culture}

Not everyone was happy about what seemed to be an increasingly affluent, transatlantic society during the 1950s. A January 1958 editorial in the

${ }^{86}$ Robert Colls, The Collier's Rant: Song and Culture in the Industrial Village (London: Croom Helm, 1977), 17. For a critique of Colls's book, see Dave Harker, "The Original Bob Cranky?," Folk Music Journal 5 (1985): 48-82.

87 Dennis, Henriques, and Slaughter, Coal is Our Life, 33.

88 Ibid., 36.

89 "World of the Miner," The Times, 19 August 1961, 10.

90 Paul Ferris, "The Birmingham Ballads," Observer, 27 August 1961, 17.

91 Ibid.

92 "Poetic Documentary with Worker-Heroes," The Times, 27 January 1962, 4.

93 Ibid.

94 Ibid. 
CPGB newspaper the Daily Worker, for example, declared that "the British people cannot stand by and watch this economic sabotage" but must "struggle against the monopolists and their Tory government." 95 Indeed, although aspects of working-class life had greatly improved in the postwar period, these gains were conditional on what Selina Todd describes as workers "accepting an older power relationship that left control of workplaces, and the lion's share of the country's wealth, in the hands of the few"; despite an overall increase in wages, she notes, peacetime was still "riven by class" and escalating economic inequalities. ${ }^{96}$ Even nationalization had resulted in a different but equally remote and antagonistic managerial stratum for manual laborers. Working-class affluence, moreover, often relied on overtime work and mounting credit. Prosperity, inequality, and the rise of mass consumption thus became the focal points of a political debate during the decade in which Leftist fears coalesced around three interrelated concerns: an aversion to right-wing government stemming from a desire to redirect society toward socialism and away from the injustices of capitalism; a loathing of the rapacious advance of Americanized mass consumerism; and a belief that widespread affluence spelled the end of authentic working-class identity and an impending loss of political commitment, opposition, and resistance.

As Dominic Sandbrook notes, to many people during the late $1950 \mathrm{~s}$ "Britain felt like a country on the verge of an exciting new era of opportunity and possibility," whereas to others "it felt like a country on the brink of a descent into materialism and madness." 97 Given that the 1959 Labour defeat was seen to indicate the party's demise as a viable alternative and thus to require a fundamental re-examination of its outlook, challenges to Tory consensus came principally from the nascent New Left - a heterogeneous group of radicals aiming to delineate a space between the polarized extremities of Cold War politics. ${ }^{98}$ In his evangelizing editorial for the first issue of New Left Review in January 1960, Stuart Hall stated: "We are convinced that politics, too narrowly conceived, has been a main cause of the decline of socialism in this country"; the "humanist strengths of socialism," he continued, "must be developed in cultural and social terms, as well as in economic and political," in order to attract young people, unify a fragmented movement, and

95 George Matthews, “A Prosperous and Happy 1958,” Daily Worker, 1 January 1958, 1.

${ }_{96}$ Selina Todd, The People: The Rise and Fall of the Working Class, 1910-2010 (London: John Murray, 2014), 169.

97 Sandbrook, Never Had It So Good, 30.

98 The New Left Review represented the merging of Universities $\mathcal{E}$ Left Review with The New Reasoner under the editorship of Stuart Hall; see Michael Kenny, "Communism and the New Left," in Opening the Books: Essays on the Social and Cultural History of British Communism, ed. Geoff Andrews, Nina Fishman, and Kevin Morgan (London: Pluto Press, 1995): 195-209. 
engage a broader spectrum of support. ${ }^{99}$ What was needed, Hall urged, was a critical language "sufficiently close to life" with which to discuss mass culture, as it was "directly relevant to the imaginative resistances of people who have to live within capitalism." 100 As a "movement of ideas" aligned with both the CND and trade unionism, Hall hoped that the British New Left would bring about "a genuine dialogue between intellectual and industrial workers": the "distant wariness" between these two groups, he asserted, "must be broken down." ${ }^{101}$ Ultimately, for Hall, the New Left's duty was to provide a reconciliatory platform in response to the "frozen monoliths of the Labour Movement": the "last refuge of scoundrels today," he concluded, is found in "the cry that we must sink our differences in the interests of Party Unity." 102

MacColl's stance clearly did not align with such revisionism: indeed, he represented the very "frozen monoliths" against which the younger generation was reacting. Ben Harker therefore claims that as a "rearguard defense" of CPGB policies the programs were "a riposte to New Left positions." 103 Factions within the heterodox New Left, however, actively embraced the early radio ballads-in the inaugural issue of the New Left Review, no less-as a means of fostering Hall's "imaginative resistance." As paradigms of folk art, such work was seen as the intramural remedy for the ills of a trite and aggressively commercialized music industry. Predicated on nostalgia for pre-modern craftsmanship articulated via Morris, a review article by Bill Holdsworth inspired by Song of a Road began by eulogizing "the romance of creating, even though it be by using a pick and shovel."104 Through the radio ballads, Holdsworth continued,

MacColl is making a great contribution in the fight against the mass pop-culture.... He has brought alive the personal drama of our own day and age. When every channel of our senses are flooded with sickly sentiment wrapped up in a commercialised sex packet, it is rare to find any expression of truth and reality getting through. Yet it does. More so during the short lived period of skiffle. (Oh, I do wish those Denmark Street hounds had left the kids alone.) ${ }^{105}$

Holdsworth described being thrilled, on hearing The Ballad of John Axon, by the "rendering of a contemporary event breaking through the thick

99 Stuart Hall, "Editorial," New Left Review 1 (1960): 1-3, at 1.

100 Ibid.

101 Ibid., 2, 1.

102 Ibid., 2.

103 Ben Harker, "Class Composition: The Ballad of John Axon, Cultural Debate and the Late 1950s British Left," Science Eे Society 73 (2009): 340-55, at 344.

104 Bill Holdsworth, "Songs of the People," New Left Review 1 (1960): 48-49, at 48.

105 Ibid. 
mud of mass pop culture on the mass media itself." ${ }^{106}$ For politically committed folk revivalists this idea was pivotal: MacColl believed that the traditional songs he cherished should "serve as a model for contemporary popular music." 107 The odds were not in his favor: as Ferris bemoaned in relation to the BBC series Hootenanny recorded at MacColl's Ballads and Blues club, "when songs like this ... take the place of pop in broadcasting, the millennium will be just around the corner."108

In the same issue of New Left Review, Brian Groombridge and Paddy Whannel took up a related theme, punning that something was "rotten" in Denmark Street (Britain's Tin Pan Alley). Advocating an "astringent tone" in discussions of popular song that would "avoid both the tyrannical asceticism of the communist states... and the slap-happy, standardless euphoris [sic] of fan publicity," they proposed that most mass-consumed music was simply "bad," as it involved an "abuse of the means of communication in contemporary society." ${ }^{109}$ Poor songs, they asserted, are those that "narrow our sympathies, blunt our sensibilities and trivialise our feelings"; hence, integrity in engagement with mass culture was "essential to democracy." 110 In spite of British cultural Marxism's later emphasis on resistance and consumption over production, early New Leftists shared an outlook with the philosophical tenets of Frankfurt School critique. ${ }^{111}$ Mass-produced music, in short, was seen to be homogenizing, irresponsible, materialistic, and escapist-and thus a moral threat to political engagement. Harboring the potential to expand sympathies, sharpen sensibilities, and elevate emotions, by contrast, the radio ballads offered a conscientious alternative. The overriding irony, however, was that commercial popular song had been central to vernacular culture ever since the advent of cheap print - a domain systematically ignored by generations of folksong collectors. ${ }^{112}$

106 Ibid.

107 MacColl, Journeyman, 338.

108 Paul Ferris, "Radio Notes," Observer, 1 March 1959, 16. See also Eric Winter, "The Flowers of Manchester"; and, on the US hootenanny craze, Ronald D. Cohen, Rainbow Quest: The Folk Music Revival and American Society, 1940-1970 (Amherst: University of Massachusetts Press, 2002).

109 Brian Groombridge and Paddy Whannel, "Something Rotten in Denmark Street," New Left Review 1 (1960): 52-54, at 52. On the music discussed, see Gillian A. M. Mitchell, "A Very 'British' Introduction to Rock 'n' Roll: Tommy Steele and the Advent of Rock 'n’ Roll Music in Britain, 1956-1960,” Contemporary British History 25 (2011): 205-25.

110 Groombridge and Whannel, "Something Rotten in Denmark Street," 54.

111 Such arguments recall Theodor W. Adorno's infamous "On Popular Music" (1941) in idem, Essays on Music, ed. Richard Leppert (Berkeley: University of California Press, 2002): 437-69. See Richard Middleton, Studying Popular Music (Milton Keynes: Open University Press, 1990); and Max Paddison, Adorno's Aesthetics of Music (Cambridge: Cambridge University Press, 1993).

112 See Christopher Marsh, Music and Society in Early Modern England (Cambridge: Cambridge University Press, 2010); Fox, Oral and Literate Culture; Paula McDowell, "The 
Although the radio ballads were impelled by a fervently egalitarian agenda and, as Cox maintains, "deliberately let working people have their say rather than speaking for them," MacColl's treatment of laboring culture demands careful scrutiny. ${ }^{113}$ On the one hand, what MacColl portrayed as the "living speech" of marginalized working-class subjects and their intimate oral histories were being revitalized and aired on national radio for the first time in a uniquely sympathetic and respectful manner-demonstrating what MacColl felt to be similarities with traditional ballads in "moments when the flat, ongoing narrative would suddenly be illuminated by a phrase of extraordinary potency." $" 114$ On the other hand, the ways in which the radio ballads' vignettes were sought out, selected from the corpus of field recordings, and shaped through dramatic collage and the praxis of songwriting were elided and left wholly in the hands of MacColl, Parker, and Seeger. The programs, in other words, engaged working-class voices to authenticate the political vision of gatekeepers with access to mass media conduits such as the BBC. ${ }^{115}$ In so doing, I want to argue, they misconstrued the very thing they desired to illuminate-ventriloquizing their subjects in service of a folkloric ideal. MacColl's entire output harbored this tendency to instrumentalize the aesthetic to didactic ends. ${ }^{116}$

In his book The Uses of Literacy-a classic semi-autobiographical account of northern working-class life published in 1957-Richard Hoggart diagnosed these errors as being typical of a "middle-class Marxist's view":

He pities the betrayed and debased worker, whose faults he sees as almost entirely the result of the grinding system which controls him. He admires the remnants of the noble savage, and has a nostalgia for those "best of all" kinds of art, rural folk-art or genuinely popular urban

Manufacture and Lingua-facture of Ballad-Making': Broadside Ballads in Long EighteenthCentury Discourse," The Eighteenth Century 47 (2006): 151-78; Oskar Cox Jensen, "The Travels of John Magee: Tracing the Geographies of Britain's Itinerant Print-Sellers, 1789-1815," Cultural and Social History 11 (2014): 195-216; Dave Russell, Popular Music in England, 1840-1914, rev. ed. (Manchester: Manchester University Press, 1997); Derek B. Scott, Sounds of the Metropolis: The Nineteenth-Century Popular Music Revolution in London, New York, Paris, and Vienna (New York: Oxford University Press, 2008); and John Storey, ed., The Making of English Popular Culture (Abingdon: Routledge, 2016). Lloyd, for example, had disregarded commercial popular song in his work even though it was central to the life of mining communities: A. L. Lloyd, ed., Come All Ye Bold Miners: Ballads and Songs of the Coalfields (London: Lawrence \& Wishart, 1952). As a corrective, see Dennis, Henriques, and Slaughter, Coal is Our Life.

113 Cox, Set into Song, 87.

114 MacColl, Journeyman, 313; and idem, "The Radio Ballads."

115 On the mechanics behind this point, see Pamela J. Shoemaker and Tim P. Vos, Gatekeeping Theory (New York: Routledge, 2009).

${ }^{116}$ See Owen Holland, "Remembering Ewan MacColl: The Agency of Writing and the Creation of a Participatory Popular Culture," New Theatre Quarterly 28 (2012): 80-93. 
art, and a special enthusiasm for such scraps of them as he thinks he can detect today. He pities and admires the Jude-the-Obscure aspect of working-people. Usually, he succeeds in part-pitying and partpatronising working-class people beyond any semblance of reality. ${ }^{117}$

Hoggart's impeachment of such "positive over-expectation" is germane to the work of both Lloyd and MacColl-self-taught working-class intellectuals who, through the bequest of Marxist rhetoric, had ironically lost touch with aspects of the very culture they claimed as their own. ${ }^{118}$ Stressing that "we need to avoid any suggestion of a sense of heroism in the people... who actually live this kind of life," Hoggart offered an account of working-class existence diametrically opposed to MacColl's heightened representations. ${ }^{119}$ As Hoggart was at pains to point out, British workingclass people were "generally suspicious of principles before practice... [and] non-political and non-metaphysical in their outlook"; earnest trade union activists, he noted, formed only a small (albeit highly vocal) minority. ${ }^{120}$ In contrast to the solemn archetypes manifest in The Big Hewer, the true working-class hero, in Hoggart's assessment, was in fact a comic wit, "the cheerful, not the romantic, hero"-precisely the aspect that had been overlooked during fieldwork for the radio ballads. ${ }^{121}$

Hoggart was not alone in holding such views. Twenty years earlier, Orwell had outlined a similar critique in The Road to Wigan Piera polemic revolving around the notion that orthodox socialism was less an organic expression of working-class solidarity than a condescending creed imposed by well-meaning intellectuals. Fuelled by communist rhetoric, Orwell claimed, socialist literature and the Daily Worker were written de haut en bas; the closest thing to genuine working-class culture, he proposed, was actually "a good musical-hall comedian." ${ }^{22}$ Plenty of people, Orwell noted, "of working-class origin" were "socialists of the theoretical bookish type"-but, he protested, "they are never people who have remained working men; they don't work with their hands." ${ }^{23}$ In contrast to his parents-his mother a charwoman and his father an iron moulder, semi-professional entertainer, and working-class radical who apparently did not tolerate unskilled workers-MacColl forged a career entirely within the performing arts as an actor, playwright, dramaturge,

117 Hoggart, The Uses of Literacy, 6.

118 Ibid., 4.

119 Ibid., 36.

120 Ibid., 77, 86, 288. Hoggart's views thus aligned with the more empirical conclusions drawn by Dennis, Henriques, and Slaughter, Coal is Our Life.

121 Hoggart, The Uses of Literacy, 117.

122 George Orwell, The Road to Wigan Pier (London: Penguin, 2001 [orig. pub. 1937]), 163.

123 Ibid., 164. 
singer, and songwriter. ${ }^{124}$ As such, he resembled Orwell's caricature of the intensely self-conscious Marxist who admires Stalin and lashes himself "into frenzies of rage against the class to which, by birth or by adoption, he himself invariably belongs." ${ }^{125}$ Underpinning this outlook was a gendered epitome: "the more or less mythical figure of a 'proletarian,' a muscular but downtrodden man in greasy overalls." 126 This epitome was the driving force behind the idea of industrial balladry. In Orwell's opinion, such a conceptualization of socialism was in danger of neglecting its declared ideals of justice, liberty, and humane understanding in favor of "crankishness, machine-worship and the stupid cult of Russia." 127

The radio ballads thus exemplified a political ideology that had been called into question by a succession of prominent Leftist thinkers in Britain. Indeed the very same year as The Ballad of John Axon was first broadcast, Raymond Williams argued that "there are in fact no masses; there are only ways of seeing people as masses." 128 The "crude and mechanical" notion of a bourgeois realm existing independently from an authentic proletarian culture, Williams asserted, must be rejected, along with "the manufacture of an artificial "working-class culture", opposed to common traditions. ${ }^{129}$ Writers across the political spectrum, in other words, had been guilty of envisaging the working class as an undifferentiated mob-sometimes as gullible consumers and other times as galvanized rebels. Echoed in the surrounding discourse, the radio ballads' chief shortcoming was this imaginative fabrication of a cohesive and idealized political community counterpoised to a monolithic mass of inauthentic consumers: in truth, there was no such thing as "the British working class" but instead a diverse multitude of British laboring people of varying political opinion, taste, and employment. ${ }^{130}$ Rather than force society to conform to a deterministic vision or accept given formulae, however benevolent, that presumed ownership of the future, Williams concluded, critical intellectuals needed to turn their attention toward a more flexible, democratic, and ecological understanding of culture as haphazard "natural growth"-freeing themselves from the long and

${ }^{124}$ Harker, Class Act, 8.

125 Orwell, The Road to Wigan Pier, 167.

126 Ibid., 211.

127 Ibid., 201.

128 Raymond Williams, Culture and Society, 1780-1950 (Nottingham: Spokesman, 2013 [orig. pub. 1958]), 300.

${ }^{129}$ Ibid., 321. On the mutable nature of popular culture across such boundaries, see for example Lawrence W. Levine, Highbrow/Lowbrow: The Emergence of Cultural Hierarchy in America (Cambridge, MA: Harvard University Press, 1988).

${ }^{130}$ Jon Lawrence, "Class, 'Affluence' and the Study of Everyday Life in Britain, c. 1930-1964," Cultural and Social History 10 (2013): 273-99; Sandbrook, Never Had It So Good, 35; and Andrew August, The British Working Class, 1832-1940 (Harlow: Pearson Longman, 2007). 
misleading histories of "dominative" thought. ${ }^{131}$ Although "the clenched fist is a necessary symbol" for the advancement of working-class interests, he stressed, "the clenching ought never to be such that the hand cannot open, and the fingers extend, to discover and give a shape to the newly forming reality." 132 The clenched fist of MacColl's songwriting was never able to offer such exploration or reconciliation, closed as it was to ideas outside his comparatively anachronistic interpretation of Marxism.

\section{On the Road to Victory}

One review of The Big Hewer equated the contrast between documentary field recordings and MacColl's "big-gestured" ballads to that between "a real working man and a civic statue to the dignity of labour in the socialrealist style." ${ }^{133}$ Given a certain ambiguity of terminology at the time, the statement points toward this reviewer's intention of portraying early radio ballads as instantiations of communist-and more specifically Stalinist-propaganda. ${ }^{134}$ Only three years before the broadcast of The Ballad of John Axon, MacColl had published a song titled "Ballad of Stalin":

Joe Stalin was a mighty man, a mighty man was he,

He led the Soviet people on the road to victory.

All through the revolution he fought at Lenin's side,

And they made a combination till the day that Lenin died.

$[\ldots]$

Joe Stalin was a mighty man and he made a mighty plan;

He harnessed nature to the plough to work for the good of man;

He's hammered out the future, the forgeman he has been

And he's made the workers' state the best the world has ever seen. ${ }^{135}$

Such work was symptomatic of the CPGB as a "living contradiction"-its members condemning imperialism and inequality but supporting the Soviet Union uncritically, oblivious to revolutionary terror and the Gulag. ${ }^{136}$ Dave Harker thus argues that The Big Hewer manifested a "socialist-realist' prescription" - a conclusion reiterated by Alun Howkins, who proposes that the radio ballads "smacked... of the cruder kinds of socialist realism at best and Stalinism at worst." ${ }^{137}$ Similarly, Ben

131 Williams, Culture and Society, 336-37.

132 Ibid., 335.

133 "Poetic Documentary with Worker-Heroes." This source is misquoted by Harker in Class Act, 152.

134 See, for example, Max Rieser, "The Aesthetic Theory of Social Realism," Journal of Aesthetics and Art Criticism 16 (1957): 237-48.

135 Ewan MacColl, "Ballad of Stalin," Sing 1, no. 5 (1955): 92-3.

136 Eaden and Renton, The Communist Party of Great Britain, 84.

137 Harker, One for the Money, 184; and Alun Howkins, "History and the Radio Ballads," Oral History 28 (2000): 89-93, at 92. 
Harker suggests that "in its assumptions and aesthetic strategies The Ballad of John Axon was a late exercise in the genre of socialist realism."138 To see if these critics are right, it is worth taking a short detour through Soviet aesthetics.

The difference between socialist realism and social realism is commonly drawn between a style functioning as a Stalinist illusion and one that relied on Marxism-Leninism to criticize or oppose ruling elites by representing structural socio-economic inequalities under capitalism. This view of socialist realism, however, is overly simplistic. Socialist realism was seen by Soviet authorities as part of the fabric of political ontologybelieving, as Brandon Taylor notes, that "the transformation of social life under the guidance of the Communist Party required a complete reeducation of humanity in all its cultural habits." ${ }^{139}$ In this context, communist art involved the depiction of society in the teleological guise of its "revolutionary development." Consequently, as Boris Groys argues, the avowal of smiling heroism in figurative painting and sculpture must be understood in relation to a larger transformational plan to aestheticize culture under Stalin: as a style intended to be "projective rather than mimetic," socialist realism was the visualization of a collective aspiration revolving around the reforged New Soviet Person. ${ }^{140}$ Indeed, Evgeny Dobrenko claims that socialist realism's purpose was not to be escapist propaganda but rather to "produce reality by aestheticizing it." 141 In revolutionary culture, Dobrenko argues, socialism "was above all a political and economic project," whereas in Stalinist culture it became "a representational project par excellence" - a scheme eschewing unresolved social dissonances by depicting culture under the conditions of purportedly "realized" socialism. ${ }^{142}$ The Stalinist conception of socialism manifested, as Petre Petrov argues, a "turn toward truth understood as an ontological happening" whereby the state "acts as if it were merely the power of codifying and securing objective realizations" untethered from subjective belief. ${ }^{143}$

138 Harker, “Class Composition,” 348.

139 Brandon Taylor, "Socialist Realism: 'To depict reality in its revolutionary development," in A Concise Companion to Realism, ed. Matthew Beaumont (Oxford: WileyBlackwell, 2010), 160-75, at 163; and Ronald Grigor Suny, ed., The Cambridge History of Russia: Volume III, The Twentieth Century (Cambridge: Cambridge University Press, 2015). See also Marina Frolova-Walker and Jonathan Walker, Music and Soviet Power, 1917-1932 (Woodbridge: The Boydell Press, 2012); and Marina Frolova-Walker, Stalin's Music Prize: Soviet Culture and Politics (New Haven: Yale University Press, 2016).

140 Boris Groys, The Total Art of Stalinism: Avant-Garde, Aesthetic Dictatorship, and Beyond, trans. Charles Rougle (Princeton: Princeton University Press, 1992), 113.

141 Evgeny Dobrenko, Political Economy of Socialist Realism, trans. Jesse M. Savage (New Haven: Yale University Press, 2007), 4.

142 Ibid., xi.

143 Petre Petrov, "The Industry of Truing: Socialist Realism, Reality, Realization," Slavic Review 70 (2011): 873-92, at 886, 887. 
This vision of the inexorable unfolding of socialism demanded a unified, official art to the exclusion of all other approaches. Socialist realism was therefore not a propagandistic deception, but rather a dynamic partypolitical instrument seen to be capable of generating the very "real" socialism it depicted-an aesthetic necessarily untethered from the realm of documentary investigation.

In spite of MacColl's provocative Stalinism, the BBC radio ballads could thus never be instantiations of socialist realism. MacColl's aesthetics instead recall the vanguard Proletkult movement accompanying the "euphoric optimism" of the 1917 revolution that, as Lynn Mally stresses, saw its task as founding a new cultural order "dominated by a proletarian class spirit." ${ }^{44}$ Matthew Cullerne Bown notes that Proletkult poetry, for instance, was distinguished by its "hypertrophied industrial romanticism." ${ }^{45}$ The radio ballads fit much more comfortably within this presocialist realist period of class struggle prior to the "realization" of socialism in the purportedly conflictless society of the 1930s. As Bown argues, inchoate realist aesthetics at the time "required a work of art to be constructed dramatically, in such a way as to reveal class conflict and its successful resolution" through a style "founded in observation of the real world and focusing on the human figure." 146

The only other parallel that could be drawn between the early radio ballads and Soviet art is the post-Stalinist emphasis on what Bown terms a "new heroic view of the ordinary person" and the tentative motion toward social critique under Khrushchev—an approach that "ran counter to the whole social ethos that had produced socialist realism." ${ }^{147}$ The aesthetics of this period marked the rise of an unofficial Severe Style engaged in depicting a new breed of hero "usually male, strikingly broad-shouldered and firm-limbed, impressively muscled, athletically posed," focusing explicitly on stoic laboring figures "built for endurance ... engaged in a grim, determined struggle." ${ }^{148}$ Accompanying the programs in the Radio Times and providing the most striking example of an equivalent fetishization of the male laboring body were Eric Fraser's distinctive monochrome drawings. ${ }^{149}$ In his illustration for The Big Hewer, in particular, Fraser emulated the programs' highly gendered modeling of working-class heroism (fig. 2).

${ }^{144}$ Lynn Mally, Culture of the Future: The Proletkult Movement in Revolutionary Russia (Berkeley: University of California Press, 1990), 258, 254.

145 Matthew Cullerne Bown, Socialist Realist Painting (New Haven: Yale University Press, 1998), 52.

146 Ibid., 128.

147 Ibid., 266, 403.

148 Ibid., 397.

149 See Sylvia Backemeyer, ed., Eric Fraser: Designer and Illustrator (London: Lund Humphries, 1998); and David Wootton, ed., Eric Fraser, 1902-1983 (London: Chris Beetles, 2013). 
Figure 2. "The Big Hewer” by Eric Fraser, Radio Times, 10 August 1961. Reproduced by kind permission of Mary and Geoffrey Fraser.

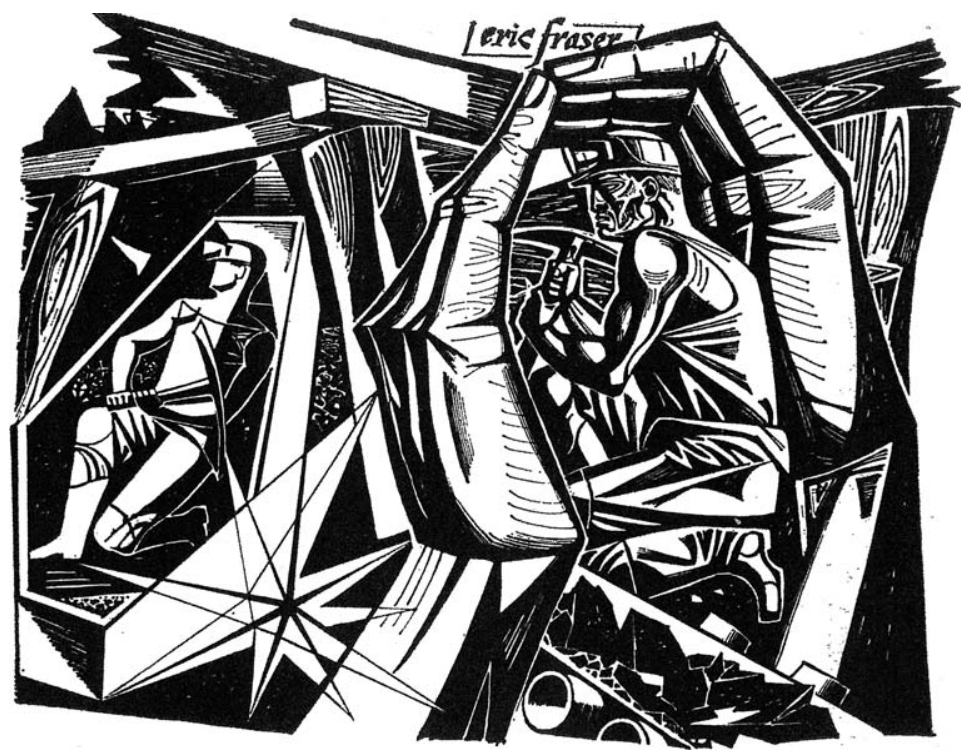

\section{Come All You Gallant Labouring Men}

If, given MacColl's CPGB affiliations, the radio ballads are positioned in relation to Soviet art, however, we are liable to miss the relevance of concurrent ideas in Britain concerning social realism-a movement defined against and yet entangled with the mercurial orthodoxies of communism. Whereas socialist realism was embroiled in the "realization" of socialism, social realism embraced marginality, foregrounding the powerless, tragic, and disaffected by bringing to attention social worlds hitherto sidelined, disregarded, or oppressed. Prevalent across the arts in Britain during the late 1950s and early 1960s and signaling a deep egalitarianism reaching back to the nineteenth century, social realism offered not only a radical alternative to reigning abstract expressionism in the United States and work from behind the Iron Curtain, but, more importantly, a model in which representations of class and inequality became vital to how postwar affluence and right-wing consensus were negotiated and contested. ${ }^{150}$ As Julia Hallam and Margaret Marshment propose,

150 John Gladstone, "Social Realism in American Art: The Generation of 1876," Journal of Decorative and Propaganda Arts 20 (1994): 112-39; Stephen Lacey, British Realist Theatre: The New Wave in Its Context, 1956-65 (London: Routledge, 1995); James Hyman, The Battle for Realism: Figurative Art in Britain During the Cold War, 1945-1960 (New Haven: Yale 
social realism was "constructed as an aesthetics of responsibility with a mission to incorporate its citizen subjects within the public sphere" by showing "the effects of environmental factors on the development of character through depictions that emphasise the relationship between location and identity." 151 The radio ballads should be seen in relation to this tradition of socially conscious critique, exposing a telling disparity between MacColl's Stalinist politics and his musical poetics. ${ }^{152}$

One of the signal facets of this British New Wave was what Samantha Lay describes as an "overwhelming preoccupation with working-class males"-betraying a misogyny that, she suggests, "severely limited" its claims to realism. ${ }^{153}$ This fetishization of the male laboring body was nevertheless a vital part of working-class history. Strongly gendered links existed among physically demanding jobs, respect, and the wage packet; as Joanna Bourke argues, working-class male identity was "reaffirmed by manual labour, suffused as it was with ideas of potency and heroism." 154 Union officials also frequently opposed family allowances on the grounds that they would attenuate masculine identity. ${ }^{155}$ Although young women had been mobilized for the war effort in the wake of critical labor deficiencies (taking up jobs in chemicals, munitions, transport, utilities, commerce, government, agriculture, and the armed forces), unequal wages were the norm and many sectors remained inaccessible, confining women to low-status employment. Under welfare reform and the pro-natalist discourse of the immediate postwar period, moreover, women were encouraged back into the home in response to wartime upheavals, re-inscribing the nuclear family as a normative unit based on customary gender divisions. The narrative impetus of the ballad form employed by MacColl downplayed such domestic routine by elevating those aspects of working-class life that suited heroic dramatizationrelegating the quotidian either to passages of recitative or, in the case of women's multifaceted role in modern Britain, silent omission.

University Press, 2001); David Tucker, ed., British Social Realism in the Arts Since 1940 (Basingstoke: Palgrave Macmillan, 2011); and Beaumont, ed., A Concise Companion to Realism.

151 Julia Hallam and Margaret Marshment, Realism and Popular Cinema (Manchester: Manchester University Press, 2000), 34, 184.

152 On this point, see Giovanni Vacca, "Form and Content: The Irreconcilable Contradiction in the Song-writing of Ewan MacColl," in Legacies of Ewan MacColl: The Last Interview, ed. Allan F. Moore and Giovanni Vacca (Farnham: Ashgate, 2014): 171-92.

153 Samantha Lay, British Social Realism: From Documentary to Brit-Grit (London: Wallflower, 2002), 16, 64. The most infamous example of this New Wave misogyny is John Osborne's Look Back in Anger: A Play in Three Acts (London: Faber \& Faber, 1957).

154 Joanna Bourke, Working-Class Cultures in Britain, 1890-1960: Gender, Class and Ethnicity (London: Routledge, 1994), 130.

155 Susan Kingsley Kent, Gender and Power in Britain, 1640-1990 (London: Routledge, 1999), 318. 
The asymmetrical gender politics of the early radio ballads align with the entrenchment of an essentialized male identity in both New Wave fiction and postwar working-class culture more broadly-their valiant reinforcements of masculinity compounded by representations of women as the subject of romantic attention or as patient, submissive wives focused on the employment of their husbands. In The Ballad of John Axon, for example, Isla Cameron performs a song warning other women to avoid the affections of railwaymen because of their misplaced loyalty:

I once loved a fireman; he said he loved me

He took me out walking into the country

He hugged me and kissed me and gazed in my eyes

And said, "You're as nice as the eight forty-five" $[\ldots]$

A sailor comes home when the voyage is done

A soldier gets weary of following the drum

A collier will cleave to his loved one for life

But the fireman's one love is the engine, his wife

This allegorical—and, in the final line, strangely ambiguous-confluence of women and the material aspects of heavy industry evinces a latent trope spanning field recordings throughout the programs. To quote a characteristic example from The Ballad of John Axon: "What a feeling you have when you get off the shed: you've got the engine, you've got the control of it, and what a feeling. I'm cock of the bank. There's nobody can take a rise out of me now. She's mine.... She answers to every touch." Related themes are manifest in The Big Hewer, where this trope is transferred from authority and mechanical command to the inscrutable mystery of cavities in the earth itself: "Down the pit... you know full well that she can be a nasty bitch when she likes. She can be real nasty. She's just like an angry woman." Conversely, another miner added: "I think a good pit is like a good woman."

In what he referred to as Parker and MacColl's "essays in words and music," Ferris proposed that the word "man" was prevalent, "accorded a proper dignity and put back at the centre of the songs, a hero with sweat on his brow, swearing and struggling." "156 In The Big Hewer, one miner states emphatically that it has been his "life's love" to "serve the men that work in the pit and to mix with them, because I find that they are real men." Emphasizing the role of men as intrepid providers, similar representations abound in Song of a Road and Singing the Fishing:

156 Paul Ferris, "Herring Scales," Observer, 21 August 1960, 25. 
Come all you gallant labouring men,

Leave your family and your friends;

You're needed on the job again,

On the London-Yorkshire Highway.

Now you're up on deck, you're a fisherman;

You can swear and show a manly bearing,

Take your turn on watch with the other fellows

While you're searching for the shoals of herring.

Women, by contrast, tended to function in MacColl's lyrics for The Big Hewer primarily as the voice of tragic prolepsis and lament:

Many's the time I've sat by the fire and thought how the coal is won, Waiting to hear his step at the door when another day's work was done; Many's the time I've listened and trembled to hear that warning bell, Dreading to hear that knock on the door and dreading the news they might tell.

In Song of a Road women are likewise present only as mothers singing lullabies to their children about "a man you seldom see / For he's had to roam far away from home, away from you and me." Whereas women's roles thereby revolved around the household, for men distance from the domestic sphere was romanticized as proficiency, independence, and self-realization. The overriding yet unacknowledged gaze of the early radio ballads was thus a heteronormative, male perspective: men are portrayed as courageous subjects, women as menial embellishments. Except as elaborate metaphors for sublime volatility and mechanical subservience, a woman's place was implicitly yet emphatically not in the workforce itself.

Given that female labor substantially increased during the Cold War period (in spite of the trends mentioned) and that working women were a symptom of the modernized working class, the radio ballads' cherishing of an older form of fearless, breadwinning masculinity reads as reactionary. ${ }^{157}$ Indeed Seeger notes that women's roles in the programs resulted from MacColl's firmly "pre-ecological, pre-feminist male politics."158 In 1971, by contrast, Seeger would release "I'm Gonna Be An Engineer" and be adopted as a spokesperson for the incipient Women's Movement. This song traces a female protagonist's journey through life, made more

157 Stephen Brooke, "Gender and Working Class Identity in Britain during the 1950s," Journal of Social History 34 (2001): 773-95, at 778.

${ }_{158}$ Quoted in Anne Karpf, "The Voice of the People," Guardian, 27 May 1999, 11. On Seeger, see Cohen, Rainbow Quest; Amber Good, “'Lady, What Do You Do All Day?' Peggy Seeger's Anthems of Anglo-American Feminism" (MM thesis, University of Cincinnati, 2002); and Stacy Holman Jones, "Women, Musics, Bodies, and Texts: The Gesture of Women's Music," Text and Performance Quarterly 19 (1999): 217-35. 
difficult by her unwavering desire to pursue an ostensibly masculine profession: her mother tells her of the duty to be a "lady" (and, by insinuation, livestock or chattel); her school teaches typing until it is time to "breed," reminding her that she cannot aspire to run the world, that she has no choice and no voice; and when she finally achieves her underpaid position as an engineer after studying "on the sly," the boss responds by pinching her thigh. The final irony is that when she settles down, she ends up working so that "Jimmy" can qualify as an engineer instead, and is once more reminded of her domestic obligations as both a wife and mother. Strident singing, playfully acerbic sarcasm, and expert guitar accompaniment performed by Seeger herself, however, shrewdly undercut the lyrical claim that women have "no voice." Although a similar process can be observed with respect to the radio ballads - in which the soundscape is saturated with Seeger's musical labor and her somatic gestures as an instrumentalist-the programs lack any such overt gestures of satire or irony.

But what motivated these particular depictions of working-class masculinity and femininity found in the early radio ballads? In postwar Britain, attitudes toward class, gender, and manual labor were closely intertwined-particularly as developments in the workplace, birth control, and marriage rendered gender identities increasingly uncertain. ${ }^{159}$ In this period women were subject to what Lesley A. Hall describes as "defensive reactions to a sense... that old constraints were falling away, that erotic energies nurtured by a buoyant economy and the Welfare State were threatening to break out."160 The discourse of gender, in other words, became a powerful tool to enact angry or nostalgic rejoinders to change. At the very moment in the 1950 s when traditional gender stereotypes might have had less resonance, Stephen Brooke argues, such typecasting intensified as elegies "to an older class identity, the foundation of which comprised established ideas of masculine and feminine roles." ${ }^{161}$ Articulations of gender were thus the "principal means of expressing a sense of loss"- - a device for re-establishing resilient figures of masculinity at precisely the moment they were most in jeopardy. ${ }^{162}$ Although the typical mind/body distinction implicitly vindicates a gendered hierarchy of association, as Judith Butler has noted, the early radio ballads' construction of roles relied less on this alignment of abstracted rationality with a masculine sphere than an alignment of masculinity with

159 Stephen Brooke, "Bodies, Sexuality and the 'Modernization' of the British Working Classes, 1920s to 1960s," International Labor and Working-Class History 69 (2006): $104-22$.

${ }^{160}$ Lesley A. Hall, Sex, Gender and Social Change in Britain Since 1880, 2nd ed. (Basingstoke: Palgrave Macmillan, 2013), 147.

161 Brooke, "Gender and Working Class Identity in Britain," 775.

162 Ibid., 786. 
the physical, laboring body itself-an archetype of proactive, autonomous virility that bore witness to something becoming increasingly obsolete. $^{163}$

The radio ballads thus exhibited a characteristically British form of social realism wary of women's changing role in society and anxious about an impending loss of traditional working-class masculinity brought about by economic prosperity, the long-term decline of staple industries, and the onset of a move from manufacturing to service sectors. Employing gender as a means to articulate political resistance, the programs functioned as panegyrics for the distinctiveness of British working-class culture-a milieu ostensibly threatened by the jaws of free-market capitalism, working-class affluence, and the consequences of burgeoning feminism. MacColl positioned his aestheticized distillations of such communities in classically folkloristic fashion against what many on the Left saw as an encroaching world of modernization, alienation, and cultural homogeneity. The Ballad of John Axon, for instance, deliberately foregrounded steam power shortly after the British Transport Commission published a report on the enhancement of railways that detailed concrete plans for the introduction of electric and diesel engines. ${ }^{164}$ Whereas Edwardian collectors lamented a vanishing rural peasantry, however, Cold War balladeers feared a vanishing urban proletariat. Shot through with contradictions, MacColl's work nonetheless turned this democratic sympathy for the working-class populace into an elitist disdain for popular culture and a distrust of innovation.

\section{Conclusion: Noise with a Purpose}

Tek them blokes as spout on boxes outside the factory sometimes. I like to hear 'em talk about Russia, about farms and power-stations they've got, because it's interestin', but when they say that when they get in government everybody's got to share and share alike, then that's another thing. I ain't a communist, I tell you.

Alan Sillitoe, Saturday Night and Sunday Morning (1958)

The archetypal enfant terrible of postwar realist literature, Sillitoe's Arthur Seaton was no CPGB activist-nor even, as the novel cited above makes clear, a trade union supporter. Seaton enjoys the spectacle of communist rhetoric outside his Nottingham bicycle factory only because it seems a humorous substitute for "big fat Tory bastards" and patronizing

163 Judith Butler, Gender Trouble: Feminism and the Subversion of Identity (New York: Routledge, 1990), 17.

${ }_{164}$ British Transport Commission, Modernisation and Re-Equipment of British Railways (London: Curwen Press, 1955). 
"Labour bleeders" who "rob our wage packets every week with insurance and income tax and try to tell us it's all for our own good." 165 Prototypically working class yet politically indifferent, his sole ambition is to raffle off the Houses of Parliament in order to make enough money to "settle down somewhere with fifteen women and fifteen cars." 166 His vehement anti-authoritarianism leads him not to socialist indignation or activism, but rather to brawling, alcohol, and adultery. Along with the protagonist of John Braine's aptly titled Room at the Top, Seaton epitomized the very socio-economic changes MacColl was striving to resist: hedonism, anarchy, materialistic aspiration, aversion to party politics, loss of pride in manual labor, and, ultimately, a refusal of class solidarity. ${ }^{167}$ It is hard to imagine such figures bawling protest songs or "anthems of the industrial age." Nonetheless, these novels were a more candid reflection of laboring culture during the late 1950s than the radio ballads, which, although equally chauvinistic in their outlook, were less willing to envisage a romanticized or homogeneous proletariat. In contrast to New Wave realism, the radio ballads used their characters as an instrumental counterbalance against what were feared to be increasingly moribund traditions of heavy industry. For Marxist radicals, this debate was played out with reference to a far broader ideological rivalry between opposing Cold War superpowers representing irreconcilable political alternatives: Soviet state socialism and ascendant American capitalism.

As with the New Wave, however, the tone of the radio ballads only makes sense when seen in relation to postwar prosperity and the entwined aesthetics of social realism-as elements in a dynamic network of Leftist critique provoked by a decade of Conservative political dominance, full employment alongside resistant inequalities, and the brave new world of Americanized mass culture. The programs thereby seemed to function as counterweights to Zweig's sociological findings:

The worker wants little things instead of big things, he wants them for himself rather than for society at large, he wants better and wider opportunities for getting along. Old slogans, old loyalties tend to leave him cold. The class struggle interests him less and less. The idea of the working class as an oppressed or an exploited class or the romanticized idea of the working class as foremost in the struggle for progress and social justice, is fading from his mind and is more and more replaced by the idea of the working class as a class well established and well-to-do in its own right.... Class divisions are no longer marked out by hostility and segregation. They are still there, but class feelings are less active

165 Alan Sillitoe, Saturday Night and Sunday Morning (London: Harper Perennial, 2008 [orig. pub. 1958]), 35 .

166 Ibid., 36.

167 John Braine, Room at the Top (London: Arrow Books, 2002 [orig. pub. 1957]). 
and less virulent. Also the ethos of class solidarity, of group movement, seems to be weakened, as a man thinks primarily of himself and his home. ${ }^{168}$

What Zweig appears to have detected was the slow dawning of neoliberal individualism. The programs' focus on such virile occupations as mining, steam locomotive driving, north sea fishing, and road building read as deliberate acts of opposition to what he described as a "softening in the worker" and "his feminization" in a less patriarchal culture. ${ }^{169}$ MacColl's autonomous masculine archetypes, in other words, functioned as vicarious antidotes for social change-reasserting the very stereotypes of working-class identity that were being undermined by affluence.

Evincing the impact of the CPGB's Third Period antagonism, the early radio ballads' rendering of working-class culture revealed far more about MacColl's own politics than about the communities he set into song. Vernacular understandings of class drew no normative consensus: the concept was highly mutable and, as Jon Lawrence proposes, generally employed to explain distinctions rather than assert "powerful claims about self-identity." 170 As Cannadine argues, the self-conscious groupings for which some Marxists searched never existed quite as they wished to find them. ${ }^{171}$ Imprinted with such historiography and beholden to a heroic valorization of masculine prowess, MacColl's songs conjured up a proletarian spirit where only a manifold and fluid working-class existed. In consequence, the radio ballads were never the window onto working environments they claimed to be, but rather generated visions of these communities through the lens of political nostalgia and inimical critique. In this analysis, urban working-class environments suffered the effects of external misinterpretation and outright invention in precisely the same way as rural culture had previously under the Arcadian guise of folklore.

Both Lloyd's and MacColl's work, moreover, chimed with a troubling historiographical precedent in Left humanist writing that reproduced social inequalities by marginalizing the role of women even as it challenged the dehumanizing effects of capital. Indeed, industrial production itself and the origin or expression of class consciousness were habitually rendered in exclusively masculine terms - most notably, as Joan Wallach Scott points out, in E. P. Thompson's seminal 1963 monograph The Making of the English Working Class. ${ }^{172}$ Class, in short, was a construct always

168 Zweig, The Worker in an Affluent Society, 209-10.

169 Ibid., 208.

170 Lawrence, "Class, 'Affluence' and the Study of Everyday Life in Britain," 275.

171 Cannadine, Class in Britain, 150.

172 Joan Wallach Scott, Gender and the Politics of History, rev. ed. (New York: Columbia University Press, 1999); and E. P. Thompson, The Making of the English Working Class (London: Gollancz, 1963). 
already gendered as male. Mass culture, conversely, had a long history of associations with femininity, symbolically coded as inferiority or inauthenticity-marking it as modernism's low Other while excluding women from the institutions of high culture. ${ }^{173}$ The early radio ballads reproduced these very distinctions, assigning "folk" authenticity to a masculine sphere as a bulwark against mass culture confined to an ephemeral, subordinate, feminine domain. In so doing, MacColl's radio ballads tacitly counterpoised active, localized, working-class production (in both industrial and cultural terms) with emerging patterns of passive, Americanized, and purportedly effeminate mass consumption.

Looking back on the period, MacColl suggested that this approach resulted from his childhood upbringing "in a world where unemployment, fascism and war were part of our inheritance." 174 Aligning his outlook with Lloyd's, he continued: "We were keenly aware of how the best remnants of genuine working-class forms of creative expression were being eliminated by the mass media and particularly by Tin Pan Alley and Denmark Street."175 In consequence, he affirmed, "our efforts with folk-music did not lack ideological purpose. We were intent on resisting that final act of destruction. By exposing people to the incredibly rich repertoire of traditional songs and ballads of farm-labourers, seamen, weavers, coal-miners and all those working men and women who had created them, we hoped to arrest the plasticisation of the popular culture." 176 Supported by institutions such as the BBC and labels such as Topic Records, his own professional songwriting was an attempt at creative emulation of those very working figures through a process of aesthetic mimicry that Robert Cantwell has termed "ethnomimesis." "177 Lloyd's and MacColl's unapologetically radical vision of industrial balladry was thus ultimately a tool of imaginative resistance to mass culture-a means to reassert national and class identity through music until that day when workers would come into their own.

Increasingly at odds with the mainstream folk revival, by 1961 MacColl had opened the Singers' Club in London in partnership with Seegera platform intended to rescue young people and protect traditional singers from what he described as "the ravages of the commercial machine."178

173 Andreas Huyssen, After the Great Divide: Modernism, Mass Culture, Postmodernism (Bloomington: Indiana University Press, 1986). For the ways in which geography mirrored a similarly gendered polarity in English discourse, see Dave Russell, Looking North: Northern England and the National Imagination (Manchester: Manchester University Press, 2004).

174 MacColl, Journeyman, 337.

175 Ibid.

176 Ibid.

177 Robert Cantwell, Ethnomimesis: Folklife and the Representation of Culture (Chapel Hill: University of North Carolina Press, 1993).

178 Ewan MacColl, "Why I Am Opening a New Club," Sing 5, no. 4 (1961): 65. 
Robert Shelton described this meeting ground as an evangelistic stage for MacColl's "rigorous musical and theatrical creativity," underpinned by his "steel-grip aesthetic." ${ }^{179}$ Similarly intended as antidotes to mass commerce, the radio ballads functioned as nostalgic apologetics for the integrity of an indigenous working class in the face of unparalleled socio-economic change. At the very moment when distinctively masculine working-class traditions seemed to be at risk of disappearing under the rising tide of female emancipation, Tory rhetoric, and the emergence of an affluent, materialistic, and classless utopia, Lloyd's and MacColl's conceptualization of industrial balladry generated a portrait of an unwavering British subculture damaged and defined by capitalist exploitation yet resistant to the unwelcome advance of globalized modernity.

\begin{abstract}
Focusing on a series of pioneering radio ballads produced for the BBC between 1958 and 1961 by Ewan MacColl, Charles Parker, and Peggy Seeger, this article explores representations of industrial workingclass culture in folksongs of the radical Left. Situating such work in relation to A. L. Lloyd, mass culture, the nascent New Left, gender, and the aesthetics of social realism (distinct from the project of Soviet socialist realism), I argue that early radio ballads were nostalgic panegyrics for the integrity of working-class identity in the face of unprecedented socioeconomic change. At the very moment when distinctively masculine working-class traditions seemed to be at risk of disappearing under the rising tide of affluence, Conservative Party rhetoric, female emancipation, and the emergence of a classless commodity utopia, these programs generated a portrait of an unwavering British subculture damaged and defined by capitalist exploitation yet resistant to the unwelcome advance of globalized modernity. Ultimately, such work revealed far more about MacColl's own political convictions than about the intricacies of workingclass life in Britain.
\end{abstract}

Keywords: BBC radio ballads, Ewan MacColl, folk revival, New Left, social realism

179 Robert Shelton, "Britain's Folk Scene: 'Skiffel Craze' to Clubs in Pubs,'” New York Times, 6 March 1966, 23. 